\section{Root Reconstructed with Mineral Trioxide Aggregate and Guided Tissue Regeneration in Apical Surgery: A 5-year Follow-up}

Pedro Felício Estrada Bernabé, Mariane Maffei Azuma, Luciana Louzada Ferreira, Eloi Dezan-Júnior, João Eduardo Gomes-Filho, Luciano Tavares Angelo Cintra
Department of Restorative Dentistry, Araçatuba School of Dentistry, UNESP- Universidade Estadual Paulista, Araçatuba, SP, Brazil

Correspondence: Prof. Dr. Luciano Tavares Angelo Cintra, Rua José Bonifácio, 1193, Vila Mendonça, 16015-050 Araçatuba, SP, Brasil. Tel: +55-18-3636-2867. e-mail: lucianocintra@foa.unesp.br

\begin{abstract}
Apical surgery should be considered as the last treatment option and employed when conventional endodontic treatment does not provide the expected result. In teeth undergoing apical surgery, the type of retrograde filling material is one of the factors interfering with the repair of periapical tissues. The material in intimate contact with the periapical tissues plays a fundamental role in the repair process. Several materials have been studied and indicated for use in apical surgery procedures, but the mineral trioxide aggregate (MTA) is still the most frequently used one. Guided tissue regeneration (GTR) techniques have been proposed as an adjunct to apical surgery to enhance bone healing. Here is reported a clinical case in which apical surgery was performed in conjunction with MTA-based root reconstruction of the maxillary right second incisor. After the apical surgery, a root-end cavity was prepared at the vestibular face of the involved tooth and filled with MTA. A bovine bone graft and a cortical collagen membrane were placed on the bone defect. After 5 years, clinical and radiographic assessments showed that the treatment was successful. It may be concluded that MTA presents favorable characteristics in adverse conditions and can be used in conjunction with GTR in cases involving root reconstruction.
\end{abstract}

Key Words: apical surgery, MTA, guided tissue regeneration.

\section{Introduction}

The use of mineral trioxide aggregate (MTA) was first reported in 1993 in a study where it was used for treating pathologic and iatrogenic root perforations and root-end cavities (1). MTA reportedly has adequate biocompatibility and sealing ability and is less cytotoxic than other currently used materials in endodontic therapy $(2,3)$. Moreover, it shows favorable characteristics in apical tissues. It has also demonstrated adequate sealing ability to avoid penetration by microorganisms and their byproducts (4), biocompatibility and adequate solubility properties $(3,5)$, and dimensional stability and radiopacity (5). In addition, in vivo studies have shown that MTA induces the formation of mineralized tissues such as cementum-like tissue $(3,5,6)$.

Previous studies have shown that the average success rate of apical surgery is lower than expected (7). One in every four apical surgeries was considered unsuccessful in the period from 1960 to 1979 (8). In the 1980's, the average rate increased to $50 \%$ and the size of the lesions diminished in more than 25\% of cases (9). However, the success rate of apical surgery remains less than $50 \%$ in cases of endoperiodontal lesions (6). The relatively low success rate of apical surgery is directly associated with the variety of factors that can influence the healing process in the periapical region (7).
The use of guided tissue regeneration (GTR) in apical surgery can increase the success rate of the procedure (10). Previous studies have shown that treatment of combined induced perio-endo lesions by using bioabsorbable collagen membranes with bovine bone mineral (BBM) particles provides satisfactory results for the healing process and regeneration of tissues (11). Repair or regeneration may be the final microanatomic result of wound healing (12). Both regeneration and repair depend on the nature of the wound, the availability of progenitor or stem cells, growth and differentiation factors, micro-environmental cues such as adhesion molecules, the extracellular matrix and associated noncollagenous proteins (13). The GTR technique helps create conditions that are ideal for restoration of the original structures and normal functioning of the tissues that were lost because of infection or inflammatory processes (14). A barrier, usually associated with osseous grafting materials, is applied to the defective bone to avoid infiltration by epithelial cells and gingival connective tissue. The use of the barrier membrane affords the necessary time for the differentiation, proliferation, and migration of the cells of the ligament and periodontal and alveolar bones in the bone cavity, thereby promoting the healing process. The space created by the presence of the membrane enables undifferentiated mesenchymal cells to migrate to the area 
and differentiate, thus promoting osteogenesis without interference or competition with other cell types (11).

This article describes a case of an iatrogenic root perforation that initially had a poor prognosis, but was treated successfully with the application of MTA in conjunction with apical surgery and tissue regenerative techniques, and was followed-up for 5 years.

\section{Case Report}

A 44-year-old woman presented for treatment at our Endodontics Department. The patient was in good health, had no history of systemic diseases and did not smoke. She reported pain upon palpation of the alveolar mucosa near the maxillary right central and lateral incisors (Fig. 1A). Radiographic imaging revealed periapical lesions in the maxillary right lateral incisor and also showed leakage of filling material into the periapical tissues along the vestibular portion of the maxillary right lateral incisor (Fig. 1B). The first treatment option suggested was apical surgery. The patient signed an informed consent document, which included information about the reasons for the proposed procedure and the potential risks and benefits associated with the interventions.

Asepsis of the surgical area was cleaned with iodine solution and $0.12 \%$ chlorhexidine gluconate (Periogard; Colgate-Palmolive Company, São Paulo, SP, Brazil). Prilocaine hydrochloride (3\%) with octapressin (Dentsply Ind. e Com., Ltda., Petrópolis, RJ, Brazil) was used for local anesthesia. The flap design consisted of 2 releasing incisions connected by a sulcus incision. After exposure of the lesion, a portion of the gutta-percha cone was visible, showing a tear in the vestibular portion of the maxillary right lateral incisor (Fig. $1 \mathrm{C}$ and D). The apical lesion was removed using size 85 Lucas surgical curettes (Hu-Friedy, Chicago, IL, USA) and size 35 and 36 curettes (Dentsply Maillefer, Tulsa, OK, USA), and the bone tissue was curetted. After removal of the periapical lesions, overobturation and root tooth drilling were clearly evident (Fig. 1D). The gutta-percha cone, which was within the periapical tissues, was removed (Fig. 1E). The apical root was sectioned (3-mm sections) perpendicular to the long axis of the root by using a Zekrya bur (Dentsply Maillefer) with a high-speed motor (Fig. 1F). Root-end cavities with 3 $\mathrm{mm}$ depth were prepared in the maxillary right incisors by using S15 RD, S15 LD, and S12 D/90 ultrasonic tips (GnatusSatelec; Ribeirão Preto, SP, Brazil) with an ultrasonic device (Gnatus-Satelec). A canal was then prepared along the lateral portion of the vestibular root of the maxillary right lateral incisor (Fig. 1G). The removal procedure and the root-end cavity preparation were monitored using radiographic examination (Fig. $1 \mathrm{H}$ ). Saline solution was used for irrigation during the entire surgical procedure.
At the end of the procedure, the solution was aspirated and the root-end cavities were dried with absorbent paper points (Dentsply Maillefer) (Fig. 1I). The gray Pro-Root $\mathrm{MTA}^{\oplus}$ (Dentsply Maillefer) was mixed according to the manufacturer's instructions and inserted into root-end cavities using an MAP System device (Produits Dentaires, Vevey, Switzerland) (Fig. 1J). The vestibular portion of the prepared root was completely filled with MTA, and the wall of the vestibular root of the involved tooth was rebuilt (Fig. 1L). After retrofilling, the adaptation of the material along the dentin walls was radiographically observed (Fig. $1 \mathrm{M})$. The bony defects were filled with bovine bone mineral graft (Gen-0x; Baumer S.A., Mogi Mirim, SP, Brazil) and covered with a collagen membrane (Gen-Derm; Baumer S.A.) (Fig. $1 \mathrm{~N}$ and 0 ). The patient was prescribed analgesics (naproxen $275 \mathrm{mg}$; Narocin, Teva Pharmaceutical) and instructed to rinse with $0.2 \%$ chlorhexidine gluconate (Colgate-Palmolive Company) twice a day for $30 \mathrm{~s}$ for 2 weeks. After 7 days, the stitches were removed and the patient was examined. The patient experienced no pain and showed no edema. No intraoperative or postoperative complications were observed. After 5 years, the patient was reexamined radiographically, which revealed complete repair of the periapical tissues, rendering the treatment successful (Fig. 1P and 0).

\section{Discussion}

Radiographic lesions related to root-filled teeth may persist for long periods after treatment, indicating failure of the initial treatment (15). There are several clinical factors that are associated with deteriorating persistent lesions, which can help identifying lesions that require further intervention (15). Overfilling of the root canal may occur as a result of over-instrumentation or apical root perforation. Numerous clinical studies have shown that overfilling has a negative effect on the prognosis of endodontic therapy (16). These studies indicate that filling materials might act as a foreign body, causing irritation of the periradicular tissues (17). In cases of endodontic treatment failure, nonsurgical retreatment is considered the option of choice, whenever possible (7). Apical surgery is indicated as a complementary procedure when conventional endodontic treatment or retreatment fails (18). Apical surgery is often the last resort for the treatment of apical periodontitis in cases involving a periapical cyst, a complex canal anatomy, extraradicular infections, or inadequate healing after nonsurgical retreatment (19).

In the present case, the overfilling and associated root perforation precluded nonsurgical retreatment. Therefore, apical surgery was chosen. In cases involving a tooth with a questionable prognosis, many clinicians face the dilemma of choosing between endodontic treatment or extraction 

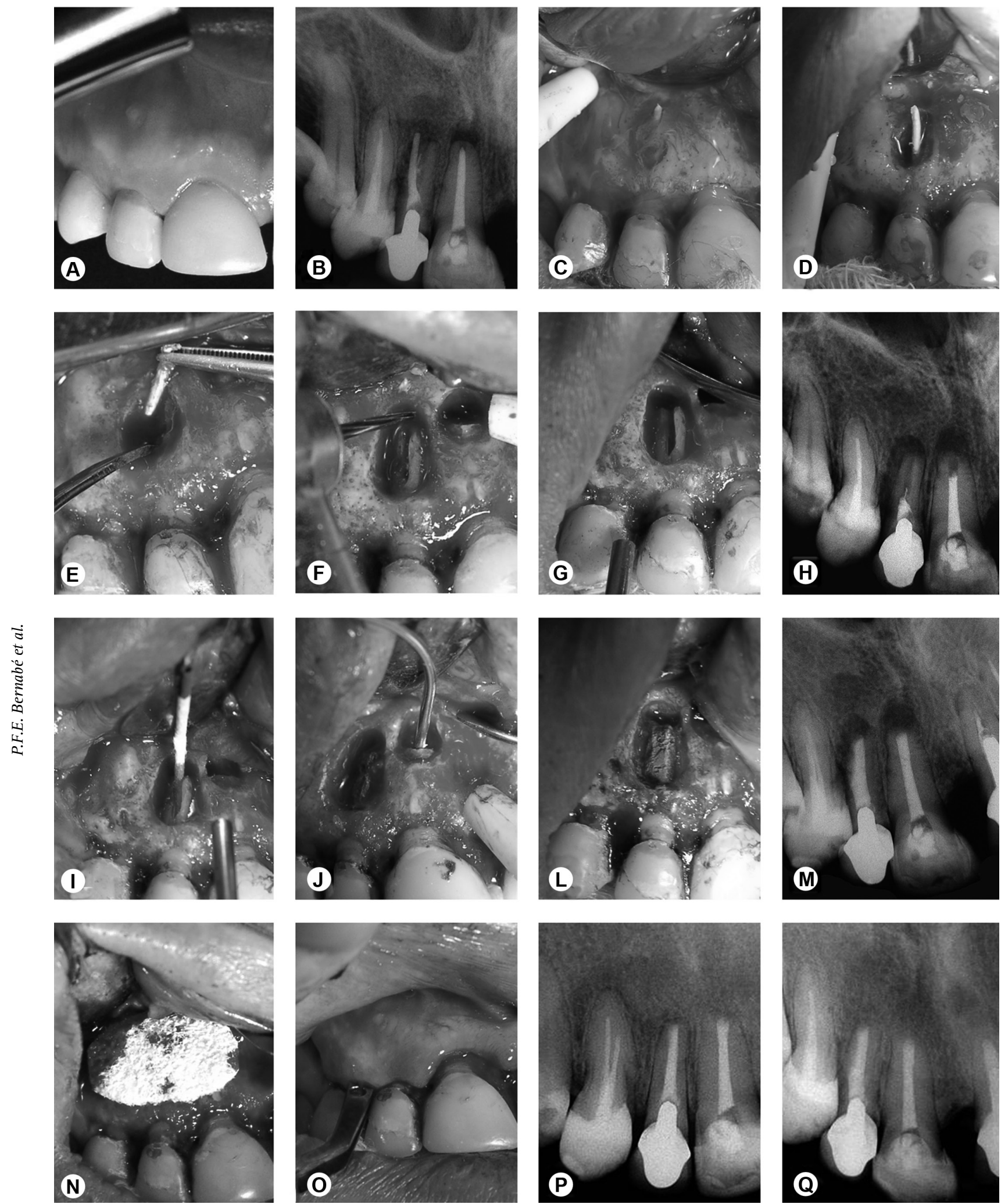

Figure 1. A: Clinical aspects of maxillary right central and lateral incisors. B: Preoperative radiographs of the maxillary right central and lateral incisors. Radiography revealed periapical lesions as well as leakage of filling material into the periapical tissues. C,D: Exposed surgical area with root-end surgery in the maxillary right central and lateral incisors, and excision of periapical lesions. E: Removal of the gutta-percha cone. F: Sectioning of the apical root perpendicular to the long axis of the root by using a Zekrya bur with a high-speed handpiece. G: Preparation of root-end cavities and the preparation of a canal along the lateral portion of the vestibular root of the maxillary right lateral incisor. $\mathrm{H}$ : Radiographic aspects of the root-end cavities preparation. 1: Drying with absorbent paper points. J: Insertion into root-end cavities by using a MAP System device. L: Vestibular portion of the prepared root was completely filled with mineral trioxide aggregate (MTA). M: Radiographic aspects of MTA adaptation. N,0: The bone cavity and the bone graft were covered with a decalcified cortical osseous membrane (Gen-Derm; Genius), and the flap was repositioned. P,Q: A follow-up radiograph taken 5 years after surgical root canal therapy showing healing of periapical lesions. 
and subsequent implant placement (20).

In this study, MTA was used to seal the apical root perforation because it can be used in areas in contact with apical tissues. MTA shows adequate sealing ability against microorganisms and their byproducts (13); it also shows good biocompatibility, adequate solubility $(2,4)$, and dimensional stability and radiopacity (4). In addition, MTA may be a viable alternative material in certain clinical applications such as capping of the dental pulp tissues, root-end closure, repair of root perforation and rootend filling because it allows regeneration of the original tissue when placed in direct contact with dental pulp and periradicular tissues $(2,5)$.

GTR is a viable treatment approach for gingival recession (21), intrabone defects (22), vertical ridge augmentation and furcation defects (23), circumferential periodontal and dental implant-associated defects (24), and in apical microsurgery $(11,12)$. In this case, a bone defect involving 2 teeth was confirmed and GTR was used. Postoperative radiograph showed radiopacity in the periapical area, suggesting complete repair in that area. In a previous study, it was observed that the use of biomaterials such as GenO $x^{\circledR}$ along with a membrane like GenDerm ${ }^{\circledast}$ provided better results than blood clotting for treating critical-size defects (25).

The distance between the margins of the bone cavity determines the type of cells that first migrate to the defect site, and consequently, the tissue that is formed (6). Fibrous scar formation may occur in cases of apical surgery with root exposure. The membranes used in apical surgeries, which may or may not be in contact with bone graft materials, function as guides for the formation of new bone, thereby accelerating the healing process. The bone graft material used in this case was an organic bovine bone that contributed to the development of new bone tissue, and therefore, was considered osteoconductive.

In this case, the lesions responded positively to the combination of surgical treatment and the used biomaterials. A combination of membrane barriers and other agents, such as bone graft materials or tissue growth factors, has been reported as a viable treatment option $(13,25)$. No intraoperative or postoperative complications were observed in this case. At the 5-year follow-up, the patient showed no clinical signs or symptoms associated with the lesion, and the radiographic examination showed progressive resolution of the radiolucency. This case showed that MTA in combination with regenerative techniques may successfully treat cases that have questionable prognoses.

\section{Resumo}

A cirurgia apical deve ser considerada como a última opção de tratamento, e realizada quando o tratamento endodôntico convencional não proporciona o resultado esperado. Em dentes submetidos à cirurgia apical o tipo de material retro-obturador é um dos fatores que interferem no reparo dos tecidos periapicais. 0 material em intimo contato com os tecidos periapicais desempenha um papel fundamental no processo de reparo. Vários materiais têm sido estudados e indicados para o uso em procedimentos de cirurgias apicais, entretanto o agregado de trióxido mineral (MTA) ainda é o mais frequentemente utilizado. A regeneração tecidual guiada (GTR) tem sido proposta como um auxiliar na cirurgia apical para melhorar a formação óssea. Aqui é relatado um caso clínico em que a cirurgia apical foi realizada em conjunto com a reconstrução radicular do incisivo lateral superior esquerdo com MTA. Após a cirurgia apical, foi preparada uma retro-cavidade na parede vestibular e o dente envolvido foi obturado com MTA. Um enxerto de osso bovino e uma membrana de colágeno cortical foram colocados no defeito ósseo. Após 5 anos, avaliações clínica e radiográfica mostram que o tratamento foi bem sucedido. Pode-se concluir que o MTA apresenta características favoráveis em condições adversas e que pode ser usado em conjunto com GTR em casos envolvendo reconstrução radicular.

\section{Acknowledgments}

This study was supported by São Paulo State Research Foundation (FAPESP Grant 2012/09987-0), SP, Brazil.

\section{References}

1. Torabinejad M, Watson TF, Pitt Ford TR. Sealing ability of a mineral trioxide aggregate when used as a root end filling material. J Endod 1993;19:591-595.

2. Bernabé PF, Gomes-Filho JE, Bernabé DG, Nery MJ,Otoboni-Filho JA, Dezan-Jr E, Cintra LT. Sealing ability of MTAused as a root end filling material: effect of the sonic and ultrasonic condensation. Braz Dent J 2013;24:107-10

3. Gomes-Filho JE, de Moraes Costa MT, Cintra LT, Lodi CS, Duarte PC, Okamoto R, et al.. Evaluation of alveolar socket response to Angelus MTA and experimental light-cure MTA. Oral Surg Oral Med Oral Pathol Oral Radiol Endod 2010;110:93-97.

4. Al-Kahtani A, Shostad S, Schifferle R, Bhambhani S. In-vitro evaluation of microleakage of an orthograde apical plug of mineral trioxide aggregate in permanent teeth with simulated immature apices. J Endod 2005;31:117-119.

5. Cintra LT, Ribeiro TA, Gomes-Filho JE, Bernabé PF, Watanabe $S$, Facundo AC, Samuel R0, Dezan-Junior E. Biocompatibility and biomineralization assessment of a new root canal sealer and root-end filling material. Dent Traumatol 2013; 29:145-150.

6. Gomes-Filho JE, de Moraes Costa MM, Cintra LT, Duarte PC, Takamiya AS, Lodi CS, et al.. Evaluation of rat alveolar bone response to Angelus MTA or experimental light-cured mineral trioxide aggregate using fluorochromes. J Endod 2011;37:250-254.

7. Song M, Jung IY, Lee SJ, Lee CY, Kim E. Prognostic factors for clinical outcomes in endodontic microsurgery: a retrospective study. J Endod 2011;37:927-933.

8. Rud J, Andreasen J0, Jensen JE. A follow-up study of 1,000 cases treated by endodontic surgery. Int J Oral Surg 1972;1:215-228.

9. Gutman J, Harrison J. Surgical endodontics. Cambridge: Blackwell Scientific, 1991;355-357.

10. Taschieri S, Corbella S, Tsesis I, Bortolin M, Del Fabbro M. Effect of guided tissue regeneration on the outcome of surgical endodontic treatment of through-and-through lesions: a retrospective study at 4-year follow-up. Oral Maxillofac Surg 2011;15:153-159.

11. Britain SK, Arx T, Schenk RK, Buser D, Nummikoski P, Cochran DL. The use of guided tissue regeneration principles in endodontic surgery for induced chronic periodontic-endodontic lesions: a clinical radiographic and histologic evaluation. J Periodontol 2005;76:450460.

12. Artzi Z, Wasersprung N, Weinreb M, Steigmann M, Prasad HS, Tsesis I. Effect of guided tissue regeneration on newly formed bone and 
cementum in periapical tissue healing after endodontic surgery: An in vivo study in the cat. J Endod 2012;38:163-169.

13. Lin $L$, Chen MY, Ricucci D, Rosenberg PA. Guided tissue regeneration in periapical surgery. J Endod 2010;36:618-625.

14. Gagnon K, Morand MA. Guided tissue regeneration in endodontics. J Can Dent Assoc. 1999;65:394-398.

15. Yu VS, Messer HH, Shen L, Yee R, Hsu CY. Lesion progression in posttreatment persistent endodontic lesions. J Endod 2012;38:1316-1321.

16. Sjögren $U$, Hagglund $B$, Sundqvist $G$, Wing K. Factors affecting the long-term results of endodontic treatment. J Endod 1990;16:498-504.

17. Nair PN, Sjögren U, Krey G, Sundqvist G. Therapy-resistant foreign body giant cell granuloma at the periapex of a root-filled human tooth. J Endod 1990;16:589-595.

18. Bernabé PF, Gomes-Filho JE, Cintra LT, Moretto MJ, Lodi CS, Nery MJ, et al.. Histologic evaluation of the use of membrane, bone graft, and MTA in apical surgery. Oral Surg Oral Med Oral Pathol Oral Radiol Endod 2010;109:309-314.

19. Karabucak B, Setzer F. Criteria for the ideal treatment option for failed endodontics: surgical or nonsurgical? Compend Contin Educ Dent 2007;28:304-310.

20. Torabinejad M, Goodacre CJ. Endodontic or dental implant therapy: the factors affecting treatment planning. J Am Dent Assoc 2010;137:973977.
21. Rotundo R, Pini-Prato G. Use of a new collagen matrix (mucograft) for the treatment of multiple gingival recessions: case reports. Int J Periodontics Restorative Dent 2012;32:413-419.

22. Goyal B, Twari S, Duhan J, Sehgal PK. Comparative evaluation of platelet-rich plasma and guided tissue regeneration membrane in the healing of apicomarginal defects: a clinical study. J Endod 2011;37:773-780.

23. Oh SL, Fouad AF, Park SH. Treatment strategy for guided tissue regeneration in combined endodontic-periodontal lesions: case report and review. J Endod 2009;35:1331-1336.

24. Simion M, Rocchietta I, Fontana F, Dellavia C. Evaluation of a resorbable collagen matrix infused with rhPDGF-BB in peri-implant soft tissue augmentation: a preliminary report with 3.5 years observation. Int J Periodontics Restorative Dent 2012;32:273-282.

25. Bernabé PFE, Melo LG, Cintra LT, Gomes-Filho JE, Dezan Jr E, Nagata MJ. Bone healing in critical-size defects treated with either bone graft, membrane, or a combination of both materials: a histological and histometric study in rat tibiae. Clin Oral Implants Res 2012;23:384-388.

Received April 29, 2013 Accepted July 18, 2013 